\title{
ENTREPRENEURIAL UNIVERSITY: CONCEPTIONS AND EVOLUTION OF THEORETICAL MODELS
}

UNIVERSIDADE EMPREENDEDORA: CONCEPÇÕES E EVOLUÇÃO DE MODELOS TEÓRICOS

Recebido em 22.06.2020 Aprovado em 06.11.2020

Avaliado pelo sistema double blind review DOI: https://doi.org/10.12712/rpca.v14i4.43186

\section{Simone Boruck Klein}

simoneboruck@,uol.com.br

Programa de Pós-Graduação em Administração/Fundação Educacional Dr. Pedro Leopoldo - Pedro

Leopoldo/MG, Brasil

$\underline{0000-0003-4956-7182}$

\section{Frederico Cesar Mafra Pereira}

professorfrederico@yahoo.com.br

Programa de Pós-Graduação em Gestão \& Organização do Conhecimento- Universidade Federal de Minas

Gerais- Belo Horizonte/MG, Brasil

$\underline{0000-0002-1971-8069}$

\begin{abstract}
In this research, the state of the art of the theme Entrepreneurial University is sought, with the objective of arousing provocations for the development of future research on this theme. Through bibliographic review, the following contributions were found: formulation of a framework of concepts and the presentation of three predominant theoretical models, considering that the first model uses Institutional Theory, the second, Systems Theory and the third, a junction of these. These contributions are associated with the presentation of theoretical approaches, used for the analysis of different objects at the Entrepreneurial University.
\end{abstract}

Keywords: Entrepreneurial University. Contemporary University. University's third mission. Entrepreneurial Education. Regional Development.

\section{Resumo}

Nesta pesquisa, busca-se o estado da arte do tema Universidade Empreendedora, com o objetivo de despertar provocações para o desenvolvimento de futuras pesquisas sobre esse tema. Por meio de revisão bibliográfica, foram encontradas as seguintes contribuições: formulação de um quadro de conceitos e a apresentação de três modelos teóricos predominantes, considerando que o primeiro modelo utiliza a Teoria Institucional, o segundo, a Teoria dos Sistemas e o terceiro, uma junção destes. A essas contribuições está associada a apresentação de abordagens teóricas, utilizadas para a análise de diferentes objetos na Universidade Empreendedora.

Palavras-chave: Universidade Empreendedora. Universidade Contemporânea. Terceira Missão da Universidade. Educação Empreendedora. Desenvolvimento Regional. 


\section{Introduction}

Knowledge is a determining factor of production for economic growth, and the actions of an Entrepreneurial University can perform an important function in knowledge-based economies (Audretsch, Keilbach, \& Lehmann, 2006). The roles that universities play in the social environment develop gradually with changes occurred in society (Etzkowitz, 2004). In 1961, Schumpeter considers the university as a propitious place for the generation and support to enabled individuals and for the modification of a productive system with a transforming basis, as well as an essential action for the development of economies in the countries.

The first generation of universities occupied itself with the purpose of teaching existing knowledge coming from Philosophy. After the First Academic Revolution, the second generation of universities begins, which start to make use of research activities for obtainment, transmission and integration of knowledge (Salamzadeh, Salamzadeh, \& Daraei, 2011). In this generation, research expands among the disciplines with reliable methods, providing scholars with participation in the creation of knowledge (Etzkowitz, 2013).

With the advent of the Second Academic Revolution, occurs the emergence of the third generation of universities, with an addition in their missions: economic and social development and knowledge transfer (Laredo, 2007). This third mission becomes part of the research activities of universities to the external economic and social worlds (Laredo, 2007), influencing the denomination Entrepreneurial Universities (Etzkowitz, 2004). In this context, the university performs a central force as a guidence of innovation, creativity and economic growth (Audretsch et al., 2006; Redford \& Fayolle, 2014).

In the literature, the conception of Entrepreneurial University places it as one of the main propellers of a social system, for which entrepreneurship can be considered both a process and a result (Jones-Evans, Klofsten, Andersson, \& Pandya, 1999; Klofsten, 2008). This strategic concept of university has been used by many of the world's leading universities, in addition to fitting in as a search for regional governments (Atlantic Canadian, 2004).

The present study results from a bibliographic research, whose objective was to analyze the conceptualizations and present different theoretical models of Entrepreneurial Universities, in view of arousing instigations and reflections for the development of this theme, as well as guiding approaches for future research referring to the Entrepreneurial University, in addition to contributing to studies that investigate changes in the relationship between the university and society.

This research is structured in six sections, including this introduction. The second section presents a discussion of the university's trajectory in the face of social and economic changes that have occurred in the world. In the sequence, the third section provides the definitions presented by the literature of the area and makes explicit a confrontation of the predominant characteristics in the referred definitions. The fourth section analyzes the three main models of the Entrepreneurial University, discussed in the literature and, in a complementary way, the fifth section, founded on previous studies, points out theories and objects of analysis at the Entrepreneurial University, providing reflections for future studies. To end up, the final considerations are presented in the sixth section.

\section{The trajectory of the university and its missions}

In its genesis, in the Middle Ages, the university is characterized by the dissemination of knowledge coming from Philosophy. In the 17th century, the search for understanding the phenomena of nature came to be known as the scientific method. With this, emerges the growing interest of individuals for the advancement of knowledge about the universe, which leads researchers to meet with the academies to discuss the discoveries and propose new questions. (Longo, 1989). 
In the middle of the 18th century, with the beginning of the Industrial Revolution, inventions result from experiments and products from artisanal ingenuity, with no interaction between the ideas of scientists and inventors in industrial processes (Longo, 1989). During this period, science remains busy with the search for answers to questions conceived by the phenomena of nature and, later, gradually, migrates to the explanation of the questions raised from the productive processes of the time. (Martins, 2014).

At the end of the 19th century happens the connection between the technology of the time and science. At that moment, technology starts to make significant use of the science present in the chemical and electric energy industries. Since then, machines, processes and products have begun to emerge from advances referring to scientific knowledge produced (Longo, 1989). From this joining process of technology with scientific knowledge, originates the incorporation of research into the university's mission, which can be called the First Academic Revolution. In this one, the dissemination of a new model of institution occurs, and the university starts to admit and practice "the principle of academic freedom and the close nexus between teaching and research” (Plonski \& Carrer, 2009, p. 108).

With the recognition of knowledge generators, universities become part of the interests of private capital, which generates an approximation with the productive sector and the attraction of investments (Etzkowitz, 2004). This approximation results in new technical-scientific knowledge, with industrial application, generated in the academy, making it possible the "translation of the research results into intellectual property and into marketable knowledge products" (Plonski \& Carrer, 2009, p. 109).

From this milestone in the mid-twentieth century, another important transformation for the university arises, the Second Academic Revolution which incorporates to its mission the intense involvement with technological innovation (Plonski \& Carrer, 2009). This new generation of the university starts to have significant relevance for economic and social development, with greater participation in the society in which it is inserted (Laredo, 2007). Thus, the university arises a proactive function in the transfer of human resources and technology (Etzkowitz \& Leydesdorff, 2000).

Figure 1 shows the three generations of universities, with their respective missions, as well as the two academic revolutions with their due characteristics.

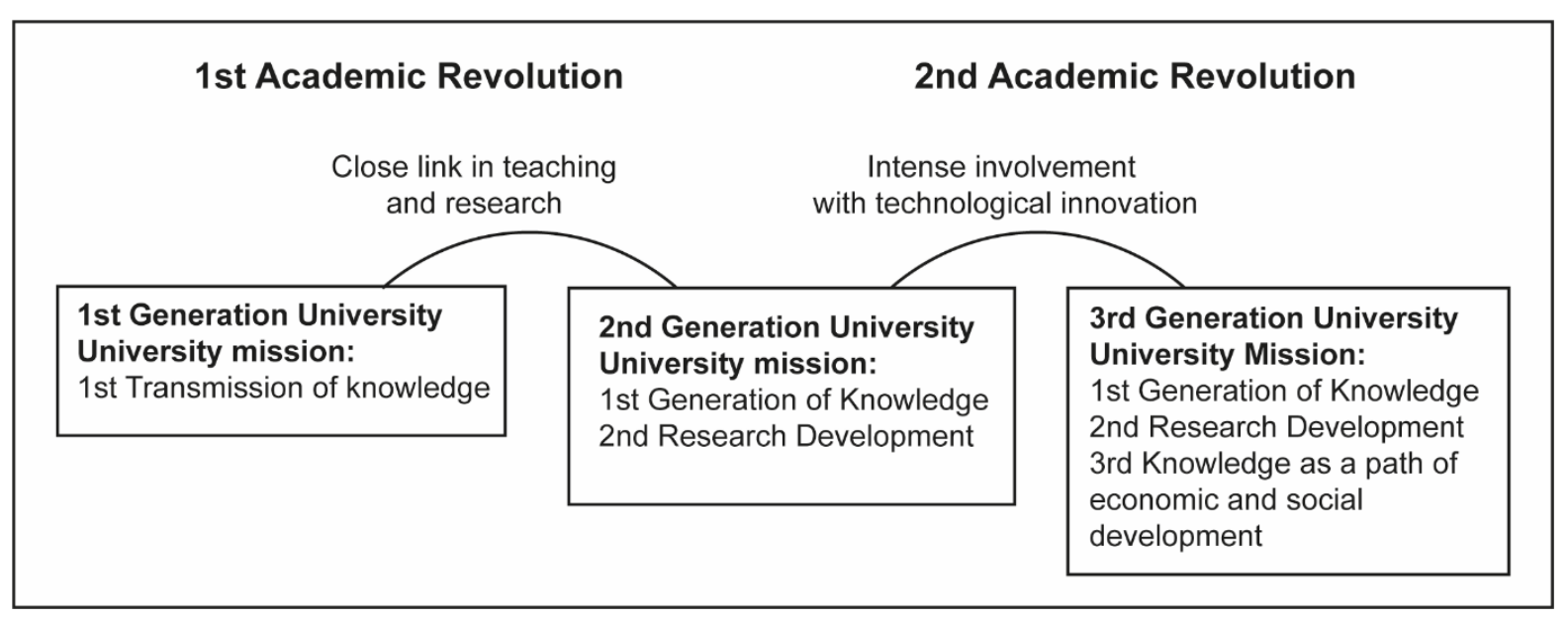

Figure 1: The trajectory of the university's mission

Source: Adapted from Etzkowitz \& Leydesdorff (2000); Etzkowitz, Webster, Gebhardt, \& Terra (2000); Eztkowitz (2004); Plonski \& Carrer (2009); Etzkowitz (2013). 
According to Etzkowitz et al. (2000), the First Academic Revolution generates an expansion of teaching, with the inclusion of methodologies for the obtainment, transmission and reintegration of the knowledge generated through researches. Research becomes thus, an indispensable tool in the teaching process, serving as a disseminator and integrator of knowledge (Etzkowitz, 2013).

The characteristics that distinguish the generations of universities show that their missions are expanded in line with social, economic and political developments, which confirms the close relationship existing between these and society. That is, the first generation of universities has the purpose of sharing knowledge; the second generation aims the use of research for the obtainment, transmission and integration of new knowledge; the third generation aggregates the economic and social developments and the focus of knowledge transfer to the missions already developed. It is inferred, therefore, that the denomination Entrepreneurial University appears in the third generation and comes from its dynamism by the search for new sources of resources and relations with the environment (Etzkowitz, 2004; Salamzadeh, Salamzadeh \& Daraei, 2011; Etzkowitz, 2013).

For Laredo (2007), the university's third mission is a critical dimension, but not new from the university activities, for what sustains a progressive transformation is the change that occurs simultaneously between the mid-1970s and 1980s. This is because the understanding of knowledge, the possibilities of circulation and the notion of absorptive capacity give origin to technological programs and triangular researches (with a candidate, a research program and a research and development department of a company), as well as the collaboration industry-university (Callon, Lare, \& Mustar, 1997; Laredo, 2007).

Simultaneously, the understanding of the innovation process evolves, moving from the linear process to the judgment of iterative and swirling models. Therewith, R\&D companies seek external actors to provide transformations, originating the innovation networks, the distributed innovation processes (Coombs, Harvey, \& Tether, 2003) and the open innovation. (Chesbrough, 2006).

This approach corroborates with the studies that define the university as a center of development in an innovative society, existing or in a process of transformation, and which, by participating internationally in research and education networks, contributes as an agent of necessary change, but not enough for construction and maintenance of the knowledge society. (Hansen \& Lehmann, 2006).

After the promulgation of the Bayh-Dole Act in the United States (USA) in 1980, the commercialization of science, the transfer of university technology, licensing, patenting and the creation of start-up / spinoff have been observed with dynamism in the USA and in countries in Europe, Asia, Australia, Canada and Israel (Grimaldi, Kenney, Siegel, \& Wright, 2011).

By distinguishing itself from traditional forms, academic entrepreneurship respects scientific norms, standards and values, in which the academic, in the vast majority of cases, produces for the university, providing it with intellectual property (Siegel \& Wright, 2015).

In the course of time, this entrepreneurship evolves similarly to the others and, today, in addition to offering technology transfer offices (TTOs) and science parks, it provides an emerging perspective that aims to provide a broader social and economic benefit to the university ecosystem, with the creation of entrepreneurial thinking for job generation. These involve students, alumni and entrepreneurs, as they also provide entrepreneurship centers, accelerators, student business plan competitions, collaboration networks with industry and alumni (Redford \& Fayolle, 2014; Siegel \& Wright, 2015).

\section{The concept of Entrepreneurial University}

The literature presents a diversity of conceptual approaches to the Entrepreneurial University phenomenon, as can be seen in Table 1. However, Guerrero-Cano, Kirby and Urbano (2006), when 
reviewing the literature in the area, mention the existence of some similar characteristics that present the importance of factors which affect universities. Among these characteristics, the following stand out: entrepreneurial activities of community members (academics and professors), implementation of different strategies to improve the creation of new enterprises and adjustments in the organizational structure of universities.

\section{Table 1 -}

\section{Referential frame of Entrepreneurial University}

(follows)

\begin{tabular}{|c|c|}
\hline Author/Year & Definition \\
\hline Etzkowitz (1983) & $\begin{array}{l}\text { Universities that are considering new sources of resources such as patents, research by contract and } \\
\text { partnerships with private companies. }\end{array}$ \\
\hline $\begin{array}{l}\text { Chrisman et al. } \\
\text { (1995) }\end{array}$ & $\begin{array}{l}\text { The Entrepreneurial University involves the creation of new enterprises by university professors, } \\
\text { technicians or students. }\end{array}$ \\
\hline Kirby (2002) & $\begin{array}{l}\text { Entrepreneurial Universities have the capacity to innovate, recognize and create opportunities, work } \\
\text { as a team, take risks and respond to challenges. }\end{array}$ \\
\hline Etzkowitz (2003) & $\begin{array}{l}\text { The Entrepreneurial University is a natural incubator, providing support structures for professors } \\
\text { and students to begin new intellectual and commercial enterprises. }\end{array}$ \\
\hline $\begin{array}{ll}\text { Jacob, } & \text { Lundqvist, } \\
\& & \text { Hellsmark } \\
(2003) & \end{array}$ & $\begin{array}{l}\text { An Entrepreneurial University is based both on the commercialization of personalized education } \\
\text { courses, consultancy services and extension activities and on commoditization (patents or startups). }\end{array}$ \\
\hline $\begin{array}{l}\text { Guerrero-Cano, } \\
\text { Kirby, \& Urbano } \\
(2006)\end{array}$ & $\begin{array}{l}\text { An Entrepreneurial University is defined as a university that has the capacity to innovate, recognize } \\
\text { and create opportunities, as well as working as a team, taking risks and responding to challenges. By } \\
\text { itself, it seeks to discover a substantial change in the organizational character to reach a more } \\
\text { promising posture for the future. }\end{array}$ \\
\hline $\begin{array}{l}\text { Salamzadeh et al. } \\
\text { (2011) }\end{array}$ & $\begin{array}{l}\text { A dynamic system that includes special contributions (resources, culture, rules and regulations, } \\
\text { structure, mission, business capacities and expectations from society, industry, government and the } \\
\text { market); processes (teaching, research, management processes, logistical processes, } \\
\text { commercialization, selection, financing and financial processes, networking, multilateral interaction } \\
\text { and innovation, research and development activities; outputs (entrepreneurial human resources, } \\
\text { effective research according to the needs of the market, innovations and inventions, entrepreneurial } \\
\text { networks and entrepreneurial centers) and aims to mobilize all its resources, skills and capacities to } \\
\text { fulfill its "third mission". }\end{array}$ \\
\hline $\begin{array}{l}\text { Kirby, Guerrero- } \\
\text { Cano, \& Urbano } \\
(2011)\end{array}$ & $\begin{array}{l}\text { The Entrepreneurial University is a natural incubator that, by adopting a strategy, coordinated in } \\
\text { critical activities (for example, teaching, research and entrepreneurship), tries to provide an adequate } \\
\text { environment in which the university community (eg.: academics, students and employees) can } \\
\text { investigate, evaluate and explore ideas that could be transformed into social and economic } \\
\text { entrepreneurial initiatives. }\end{array}$ \\
\hline
\end{tabular}

Author/Year

Guerrero-Cano, \&

Urbano (2012)

Audretsch et (2012)

Urbano

Guerrero-Cano

(2013)

Melo (2014)

Guerrero-Cano,

Urbano,

Cunningham,

Organ (2014)
Definition

(Conclusion)

An Entrepreneurial University can be defined as a survivor of competitive environments with a common strategy, oriented to be the best in all its activities (for example, having good finances, selecting good students and professors, producing quality research).

al. The role of universities is more than generating technology transfer (patents, spin-offs and start-ups) and, on the contrary, contributing and providing leadership for the creation of entrepreneurial thinking, actions, institutions and entrepreneurial capital.

\& The Entrepreneurial University needs to become an entrepreneurial organization, its members need to become entrepreneurs and its interaction with the environment needs to follow an entrepreneurial pattern.

The concept of the Entrepreneurial University refers to a proactive position of institutions, in the sense of transforming the knowledge generated, aggregating economic and social value. Thus, the basis for a successful performance is the proactive action to adapt to internal and external changes in an evolving society.

The nature of an Entrepreneurial University is such that graduates are seen not only as future job applicants, but also as future job creators, and the organization and content of teaching activities \& reflect this conception. 
Cunha \& Maculan Term that characterizes universities in which the dimension of economic and social development (2015) gained strength and made them become proactive in seeking applications for their research.

Trippl, Sinozic, \& The business model claims that universities promote the development of their regions, engaging in Smith (2015) patents, licensing and academic activities derived from university disciplines such as engineering, information technology and biotechnology in which the knowledge produced overlaps more easily with products and processes that industry and market structures can absorb.

Etzkowitz (2017) The Entrepreneurial University integrates the economic development at the university as an academic function along with teaching and research. It is this "knowledge capitalization" that is the heart of a new mission for the university, connecting universities with knowledge users more strongly and establishing the university as an economic actor in itself.

Source: Adapted from Guerrero-Cano, Urbano \& Kirby (2006); Budyldina (2018)

When observing Table 1, it is inferred that the definitions present different characteristics of the Entrepreneurial University. The first characteristic deals with the entrepreneurial activities of community members (academics and professors) and is found in the definitions that contemplate the entrepreneurial actions of the university's members towards the environment in which these ones are or will be inserted. However, some authors such as Kirby (2002), Audrestch, Hülsbeck and Lehmann (2012), Melo (2014), Cunha and Maculan (2015) and Etzkowitz (2017) emphasize the entrepreneurial activities that universities perform in the environment in which they are inserted, emphasizing the contribution to the social and economic development reached from the generation and capitalization of knowledge. This new approach to definitions can be considered as a new characteristic of the Entrepreneurial University.

The second and third characteristics listed in the referential frame refer to the strategies of improvement to the creation of enterprises, and also to changes related to the organizational structure of universities to meet the third mission. These characteristics may represent the transition phase of universities focused on research to the Entrepreneurial University, due to the reformulation of their strategies and organizational structure (Guerrero-Cano et al., 2006).

As highlighted by Etzkowitz (2017), the university represents an economic actor in the integration of economic development, teaching and research. This development has a regional nature pattern, with strategic management approaches, diversification of the financing base and promotion of entrepreneurial culture (Trippl, Sinozic, \& Smith, 2015; Pugh, Lamine, \& Jack, 2018).

Like the market, the Entrepreneurial University becomes globalized, technological, innovative and competitive, which constituted its transformation from an institution focused on internal actions to the connection between the externally interested parties (Fernández-Nogueira, Arruti, Markuerkiaga, \& Saenz, 2018). Traditional activities are redefined and expanded as the university broadens its role in innovation. Likewise, teaching is extended by students who test their knowledge in real-world situations and act as intermediaries for the connection between the university and other institutional spheres (Etzkowitz et al., 2000).

In this perspective, the Entrepreneurial University is a phenomenon that arises from the preparation of an "internal logic" of universities for academic development, expanding from conservative academic entrepreneurship to the knowledge-creating entrepreneurship (Etzkowitz, 2013).

Today, Entrepreneurial Universities play an essential role to economic development in different countries (Farsi, Imanipour, \& Salamzadeh, 2012). However, some critics defend that entrepreneurship should be maintained in a special class of higher education institutions, for they fear that intensive pecuniary interest will influence the university, leading to the loss of its role of an independent critic of society. There are still some organizations that, when identifying new companies emerging from universities as potential competitors, adopt a similar stance and argue that "universities should limit themselves to traditional academic-industrial relations such as consultation" (Etzkowitz et al., 2000, p 314) and that the 
dissemination of researches through scientific publications is considered as the most appropriate role for the institution which dedicates to the public good (Etzkowitz et al., 2000).

With the evolution of teaching and research functions, as well as the transfer of technology through links with industry and the dissemination of entrepreneurial thinking in the academic community, Entrepreneurial Universities have created an innovation infrastructure, with multiple positive effects for the micro and macroeconomic developments (Budyldina, 2018).

The transition to Entrepreneurial University presents a need for strategic directioning so that the knowledges are used, mainly, regionally. In this sense, as it occurs the expansion of the university's role in society, an image of an institution source of technological innovation and economic development is projected, which results in a trajectory of university transformation (Etzkowitz, 2017). So, the Entrepreneurial University is the improvement of the Research University by virtue of uniting an inverse and feedbacked linear dynamics with the society. (Etzkowitz, 2017).

The key elements of this trajectory, according to Etzkowitz (2017), consist of: a) organization of group research; b) creation of a research base with commercial potential; c) development of organizational mechanisms to remove research from the university as protected intellectual property; d) capacity to organize companies within the university and "graduate them"; e) integration of academic and business elements in new formats such as university research centers. These five elements are part of the special characteristics of the Entrepreneurial University. The first two ones are within the initial structuring phase of the Research University; the third integrates the phase of transition from research to entrepreneurial academic models, and the last two ones are implemented in the final phase of incorporating characteristics of the Entrepreneurial University. (Etzkowitz, 2017).

Currently, depending on the country, cultural factors, public policies and national and regional vocations of development, universities are found in different stages. Some focus on teaching and research, others are found in the process of transformation, as well as there are those already established as Entrepreneurial Universities.

\section{Models of Entrepreneurial Universities}

The theoretical models of the Entrepreneurial University that stand out the most in the literature are those of Guerrero-Cano, Kirby and Urbano (2006); IPOO model, by Salamzadeh, Salamzadeh and Daraei (2011); model by Sooreh, Salamzadeh, Safarzadeh and Salamzadeh (2011).

Guerrero-Cano et al. (2006) effect, in the model presented by them, a literature review, with emphasis on the studies of Clark (1998), Sporn (2001), Etzkowitz (2004) and Kirby (2006), as well as in some empirical studies of the time, developing a classification for the environmental factors that influence the entrepreneurial cycle of universities at the time. Under the light of Institutional Theory, they develop, then, their own model, according to Figure 2. 


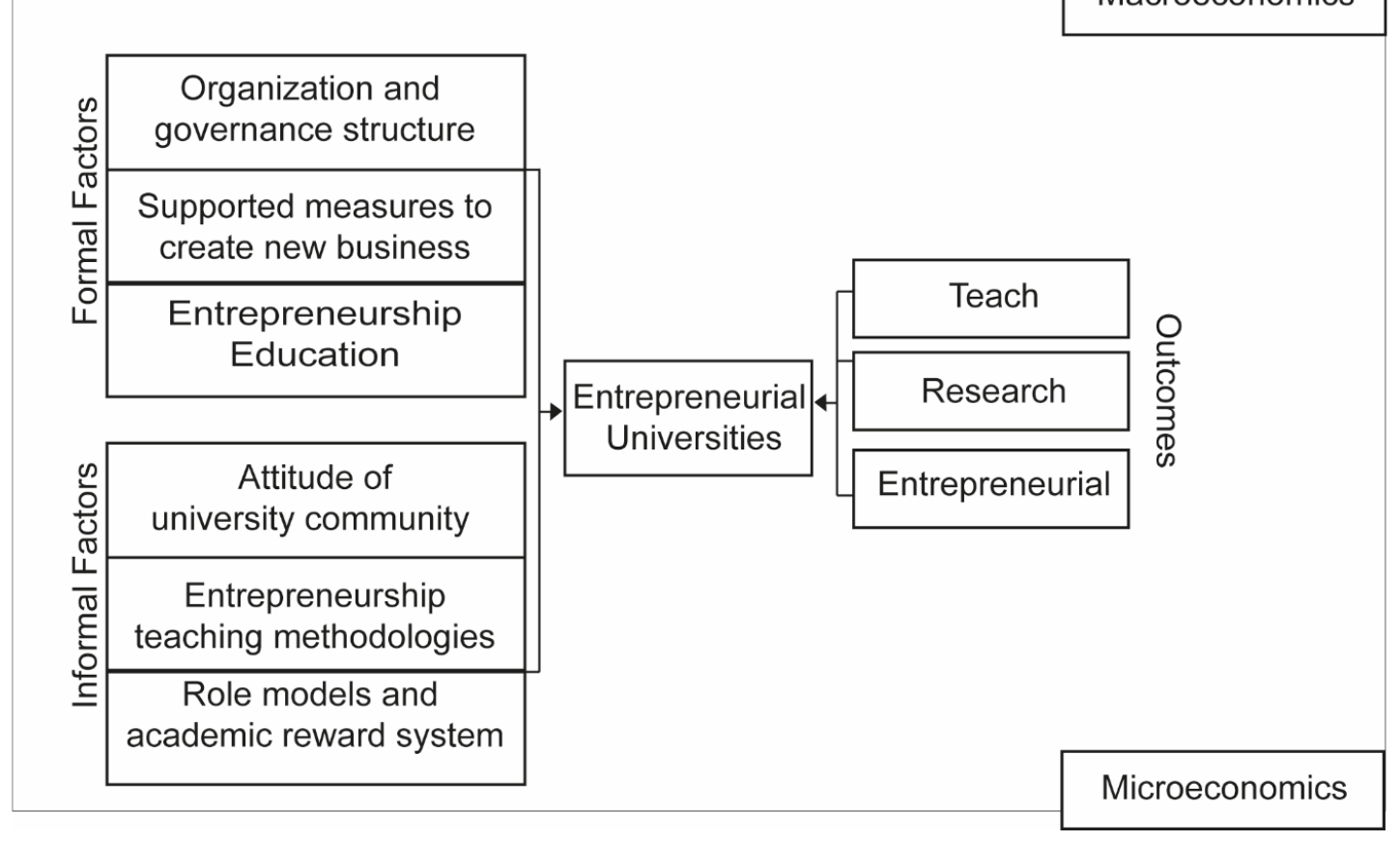

Figure 2- Guerrero-Cano, Kirby and Urbano 2006 model

Source: Guerrero-Cano et al. (2006, p. 10)

In the model by Guerrero-Cano et al. (2006), the authors base themselves in the Institutional Theory to classify factors into formal and informal. The "formal factors" are made up of the organizational structure and government of the university, measures of support to university's startups and university entrepreneurship education programs. Distinctly, "informal factors" constitute university attitudes towards entrepreneurship, models, cases, entrepreneurship disciplines in the university and university reward systems. The model also integrates the relationship between the teaching mission, which covers the educational perspective of training a graduate not only to be an applicant for a job, but also a job creator, for which the final result of the mission corresponds to the spin-off generation or new enterprises generated by students. The model also considers the existence of the environment and its conditions for the development of entrepreneurship, which can be positive or negative, affected by macro or microeconomic conditions (Guerrero-Cano et al., 2006).

Salamzadeh et al. (2011), through the Systems Theory, develop an Entrepreneurial University model, with a systematic approach to the IPOO (Input-Process-Output-Outcomes) model. The authors conduct semi-structured interviews with twenty-five specialists on the subject. After the tabulation of the interview data, the researchers meet again with the specialists, in view of a contribution through the review of the developed structure. The model originated from the respective research is presented in Figure 3. 


\begin{tabular}{|c|c|c|c|}
\hline \multicolumn{4}{|c|}{ Context } \\
\hline $\begin{array}{l}\text { Inputs } \\
\text { - Resources (Human, } \\
\text { Financial, Informational, } \\
\text { Physical) } \\
\text { - Rules and regulations } \\
\text { - Structure } \\
\text { - Mission } \\
\text { - Entrepreneurial capabilities } \\
\text { - Expectations of the society, } \\
\text { industry, government and } \\
\text { market }\end{array}$ & \begin{tabular}{|l|} 
Processes \\
- Teaching \\
Research \\
- Managerial \\
- Logistical \\
- Commercialization \\
- Selection (for students, \\
university professors and \\
staff) \\
- Funding and financial \\
- Networking \\
- Multilateral interaction \\
processes (between students, \\
university professors, staff, \\
industrial researchers, \\
entrepreneurial centers, \\
industries, policy makers \\
and society) \\
- Innovation, research and \\
development activities (IR\&D)
\end{tabular} & $\begin{array}{l}\text { Outputs } \\
\text { - Entrepreneur human } \\
\text { resources (including } \\
\text { university professors, } \\
\text { graduates, researchers, } \\
\text { and staff) } \\
\text { - Effective researches in } \\
\text { line with the market needs } \\
\text { - Innovations and inventions } \\
\text { - Entrepreneurial networks } \\
\text { - Entrepreneurial centers } \\
\text { (e.g. incubators, science } \\
\text { and technology parks, } \\
\text { spin-offs, etc.) }\end{array}$ & $\begin{array}{l}\text { Outcomes } \\
\text { Third Mission }\end{array}$ \\
\hline
\end{tabular}

Context

Figure 3 - IPOO model from Salamzadeh, Salamzadeh and Daraei

Source: Salamzadeh et al. (2011, p. 35)

When using the categorization of the IPOO model, the authors define the inputs, processes, outputs and results as "supplies", which are equivalent to elements and factors introduced in the black box of an Entrepreneurial University. As for the "outputs", they refer to the results of the transformation of inputs in the black box of process. Regarding the "results", they consider the consequences of the entry and exit process model, whose elements and factors are not the direct result of the processes, but the result of the IPOO model (Salamzadeh et al., 2011, p. 33).

With the definition of the categories, it happens the distribution of elements found in the interviews, and the composition of the "supplies" is formed by: resources (human, financial, informational and physical), rules and regulations, structure, mission, entrepreneurial capacity and expectations of the society, industry, government and the market, necessary and guiding elements of the Entrepreneurial University's activities. Yet, the composition of the "processes" consists of: teaching, research, managerial, logistical, commercialization, selection (of professors, academics and employees), financial, interaction, multilateral interaction, innovation, and research and development activities, which involve the operationalization of the Entrepreneurial University (Salamzadeh et al., 2011). The "outputs" represent the results obtained at the end of the processes, which are the products, that is, the entrepreneurial human resources (including university professors, graduates, researchers and employees), researches carried out with the alignment of market needs, innovations and inventions, entrepreneurial networks and entrepreneurial centers. With regard to "results", the following elements are considered: innovation and innovative culture, creation of socioeconomic value and human development. These elements integrate the third mission of the Entrepreneurial University (Salamzadeh et al., 2011).

Based on the models of Guerreiro-Cano et al. (2006) and Salamzadeh et al. (2011) and using the IPA (Importance-Performance-Analysis), together with the TOPSIS technique (Technique for Order Preference by Similarity to Ideal Solution), Sooreh et al. (2011) develop a model that covers the dimensions of the two base studies, exposed in Figure 4. 


\begin{tabular}{|c|c|c|}
\hline \multicolumn{2}{|c|}{ Environmental Factors } & \multirow{2}{*}{ Internal factors } \\
\hline \multicolumn{2}{|l|}{ Formal } & \\
\hline - Entrepreneurial policies & & \multirow{9}{*}{$\begin{array}{l}\text { - Existing students, academics and staff } \\
\text { - Financial resources } \\
\text { - Informative resources } \\
\text { - Entrepreneurial skills } \\
\text { - Expectations of society, government of } \\
\text { industry and market } \\
\text { - University Entrepreneurial Mission }\end{array}$} \\
\hline and missions of the & - Potential student & \\
\hline higher education system & intentions & \\
\hline - Characteristics of the & - Potential students desire & \\
\hline university manager & - Feasibility of potential & \\
\hline - Communication channels & students & \\
\hline available & - Academic intentions & \\
\hline - Business courses available & - Academic feasibility & \\
\hline - Business programs available & & \\
\hline \multirow{16}{*}{$\begin{array}{l}\text { - Organizational structuring } \\
\text { - Systems and procedures } \\
\text { - State Autonomy } \\
\text { - Determination of hierarchical } \\
\text { levels } \\
\text { - Expenditure invested in } \\
\text { support measures } \\
\text { - Expenditures invested in } \\
\text { communication channels }\end{array}$} & \multirow{16}{*}{$\begin{array}{l}\text { - Teaching resources } \\
\text { - Training teacher } \\
\text { - Rewarding environmental } \\
\text { processes }\end{array}$} & - Rules regulation \\
\hline & & - Teaching methods \\
\hline & & - Management methodologies \\
\hline & & - Logistic methods \\
\hline & & - Marketing processes \\
\hline & & - Student selection methods \\
\hline & & - Networking \\
\hline & & - Multilateral interaction processes \\
\hline & & (between students, university professors, \\
\hline & & employees, industrial researchers, \\
\hline & & business centers, industries, policy \\
\hline & & makers and society) \\
\hline & & - Innovation, research and development \\
\hline & & activities (IR \& D) \\
\hline & & • Reward systems and compensation \\
\hline & & processes \\
\hline \multirow{9}{*}{$\begin{array}{l}\text { - Entrepreneurial network } \\
\text { systems } \\
\text { - Conglomerates and } \\
\text { strategic alliances } \\
\text { - Marketing and } \\
\text { convention systems }\end{array}$} & \multirow{9}{*}{$\begin{array}{l}\text { - Custom templates } \\
\text { - Corporate culture }\end{array}$} & - Entrepreneur's human resources \\
\hline & & (including university professors, \\
\hline & & graduates, researchers and employees) \\
\hline & & - Effective researchers in line with \\
\hline & & market needs \\
\hline & & - Innovations and inventions \\
\hline & & - Entrepreneurship centers (for \\
\hline & & example, incubators, science and \\
\hline & & technology parks, spin-offs, etc.) \\
\hline
\end{tabular}

\section{Figure 4 - Sooreh, Salamzadeh, Safarzadeh e Salamzadeh model}

Source: Sooreh et al. (2011, p. 190-191)

The model proposed by Sooreh et al. (2011) is more embracing for involving the use of nine blocks, so named by the authors: formal, informal and internal inputs; formal, informal and internal processes; formal, informal and internal outputs. In the "input" block, the environmental factors raised in the study by Guerrero-Cano et al. (2006) are categorized, while the "outputs" correspond to the elements referenced at the Entrepreneurial University itself through the result of the authors' research, obtained through meetings in focus groups with specialists on the theme. The collaboration of the study by Salamzadeh et al. (2011) focuses on the structure of the model and maintains the emphasis on the "inputprocess-output" method and the elements listed. The union of this model details the procedures of the Entrepreneurial University, in addition to taking into account internal and external issues to the institution. It is noteworthy that this model is developed based on the Iranian context, and the authors emphasize that this one is suitable for that region. 


\section{Relevant studies to the theme Entrepreneurial University and research paths}

In the literature referring to the Entrepreneurial University, some authors seek to identify the relevant factors that constitute the institutions, such as Fernández-Nogueira et al. (2018), while others, such as Farsi et al. (2012), develop theoretical models, in order to explain the phenomenon.

Among the authors looking for elements that make up the Entrepreneurial University, Clark (1998) identifies, from his longitudinal study, carried out with five European universities, in the mid-1990s, five elements: (1) a strengthened guidance nucleus; (2) an expanded peripheral development; (3) a diversified financing base; (4) a stimulated academic center; (5) an integrated entrepreneurial culture. The study is considered a milestone in the literature on the topic (Farsi et al., 2012).

Rothaermel, Agung and Jiang, (2007) carry out a literature review on Entrepreneurial University and University Entrepreneurship, providing the following contributions: the definition of entrepreneurship that covers all types of activities of a typical Entrepreneurial University and the identification of four main lines of research on the theme: a) the university, organizational design and incentive and culture systems; b) productivity of technology transfer offices; c) creation of new companies; d) environmental context, which includes innovation networks.

Centobelli, Cerchione and Esposito (2019) also conduct a systematic review of the literature on the development process of these universities and provide four areas of research found: a) taxonomy of definitions; b) factors that affect the Entrepreneurial University; c) effects of entrepreneurial issues on university activity; d) measurement of the Entrepreneurial University's performance. In addition, they point to an integration model of learning processes for university innovation.

Table 2 presents some contributions from the systematic review by Centobelli et al. (2019) regarding the theoretical approaches and their evolutions, the most prominent research objects, as well as the use or not of external factors in the investigations analyzed.

Table 2-

Main theoretical approaches of studies in Entrepreneurial Universities 
(follows)

\begin{tabular}{|c|c|c|c|}
\hline $\begin{array}{l}\text { Theoretical } \\
\text { approach }\end{array}$ & Main contributions & Object of investigation & External factors \\
\hline $\begin{array}{l}\text { Triple helix model } \\
\text { (Etzkowitz \& } \\
\text { Leydesdorff, 1997) }\end{array}$ & $\begin{array}{l}\text { Klofsten et al. (1999) } \\
\text { Etzkowitz (2003) } \\
\text { Etzkowitz et al. (2008) } \\
\text { Etzkowitz (2016) } \\
\text { Carayannis \& Campbell } \\
(2009)\end{array}$ & $\begin{array}{l}\text { - Knowledge capitalization } \\
\text { - Hybrid organizational forms }\end{array}$ & $\begin{array}{l}\text { - Interaction with industry } \\
\text { conditions } \\
\text { - Interaction with } \\
\text { government policies }\end{array}$ \\
\hline $\begin{array}{l}\text { Theory of } \\
\text { entrepreneurial } \\
\text { transformation } \\
\text { paths (Clark, 1998) }\end{array}$ & $\begin{array}{l}\text { Clark (1998) } \\
\text { Clark }(2003) \\
\text { Clark }(2004)\end{array}$ & $\begin{array}{l}\text { - Reinforced direction nucleus } \\
\text { - Expansion of peripheral } \\
\text { development } \\
\text { - Diversified financing base } \\
\text { - Integrated academic center } \\
\text { - Integrated entrepreneurial culture }\end{array}$ & \\
\hline $\begin{array}{l}\text { Theory of } \\
\text { entrepreneurial } \\
\text { transformation } \\
\text { paths (Clark, 1998) }\end{array}$ & $\begin{array}{l}\text { Clark (1998) } \\
\text { Clark (2003) } \\
\text { Clark (2004) }\end{array}$ & $\begin{array}{l}\text { - Reinforced direction nucleus } \\
\text { - Expansion of peripheral } \\
\text { development } \\
\text { - Diversified financing base } \\
\text { - Integrated academic center } \\
\text { - Integrated entrepreneurial culture }\end{array}$ & \\
\hline $\begin{array}{l}\text { Grounded theory } \\
\text { of university } \\
\text { adaptation } \\
\text { (Sporn, 1998) }\end{array}$ & $\begin{array}{l}\text { Sporn (1998) } \\
\text { Sporn (2001); (2002a; } \\
\text { 2002b) } \\
\text { Sporn (2003) } \\
\text { Sporn (2010) } \\
\text { Badelt \& Sporn (2011) }\end{array}$ & $\begin{array}{l}\text { - Mission and goals } \\
\text { - Culture } \\
\text { - Structure } \\
\text { - Management } \\
\text { - Governance } \\
\text { - Leadership }\end{array}$ & - Environment \\
\hline $\begin{array}{l}\text { Theory of strategic } \\
\text { actions (Kirby, } \\
\text { 2006) }\end{array}$ & $\begin{array}{l}\text { Kirby (2007a) } \\
\text { Kirby (2007b) } \\
\text { McGowan et al. (2008) Van } \\
\text { der Sijde et al. (2008) } \\
\text { Kirby \& Ibrahim (2011a) } \\
\text { Kirby \& Ibrahim (2011b) } \\
\text { Kirby et al. (2011) } \\
\text { Kirby \& Ibrahim (2012) } \\
\text { Salamzadeh et al. (2013) } \\
\text { Hadidi \& Kirby (2015a) } \\
\text { Hadidi \& Kirby (2015b) } \\
\text { Hadidi \& Kirby (2016) }\end{array}$ & $\begin{array}{l}\text { - Senior team endorsement as role } \\
\text { model } \\
\text { - Incorporation of the teaching / } \\
\text { departmental and personal plan } \\
\text { - Implementation of monitored goals } \\
\text { - Encouragement and support } \\
\text { - Recognition and reward in terms of } \\
\text { promotion and shareholding } \\
\text { - Organization of interdisciplinary } \\
\text { research, teaching groups and } \\
\text { educational partnerships } \\
\text { - Promotion of business plan, case } \\
\text { and model competitions }\end{array}$ & \\
\hline $\begin{array}{l}\text { Structure of } \\
\text { university spinoff } \\
\text { activities (O'Shea } \\
\text { et al., 2005) }\end{array}$ & $\begin{array}{l}\text { O'Shea et al. (2007) } \\
\text { Breznitz et al. (2008) Roche } \\
\text { et al. (2008) } \\
\text { O'Shea et al. (2008) } \\
\text { Allen \& O'Shea (2010) } \\
\text { Fitzgerald et al. (2014) } \\
\text { Fitzgerald \& O'Shea (2015) }\end{array}$ & $\begin{array}{l}\text { - Institutional resources } \\
\text { - Human capital } \\
\text { - Financial resources } \\
\text { - Business resources }\end{array}$ & $\begin{array}{l}\text { - Regional infrastructure } \\
\text { - Strategic networks and } \\
\text { alliances }\end{array}$ \\
\hline $\begin{array}{l}\text { University theory } \\
\text { of entrepreneurial } \\
\text { research } \\
\text { (Rothaermel et al., } \\
\text { 2007) }\end{array}$ & $\begin{array}{l}\text { Rothaermel \& Hess (2007) } \\
\text { Rothaermel (2008) } \\
\text { Link et al. (2008) } \\
\text { Rothaermel \& Ku (2008) }\end{array}$ & $\begin{array}{l}\text { - Incentive systems } \\
\text { - Status } \\
\text { - Technology } \\
\text { - Culture } \\
\text { - Policy } \\
\text { - Faculty } \\
\text { - Location } \\
\text { - Intermediary agents } \\
\text { - Experience }\end{array}$ & $\begin{array}{l}\text { - Interaction with industry } \\
\text { conditions } \\
\text { - Interaction with } \\
\text { government policies } \\
\text { - Strategic networks and } \\
\text { aliances }\end{array}$ \\
\hline $\begin{array}{l}\text { Quadruple helix } \\
\text { model } \\
\text { (Carayannis \& } \\
\text { Campbell, 2009) }\end{array}$ & $\begin{array}{l}\text { Campbell \& Carayannis } \\
(2014) \\
\text { Campbell et al. (2015) }\end{array}$ & $\begin{array}{l}\text { - Knowledge capitalization } \\
\text { - Hybrid organizational forms }\end{array}$ & $\begin{array}{l}\text { - Interaction with industry } \\
\text { conditions } \\
\text { - Interaction with } \\
\text { government policies }\end{array}$ \\
\hline
\end{tabular}




$\begin{array}{ll} & \begin{array}{l}\text { Carayannis et al. (2015), } \\ (2016)\end{array} \\ \text { Development } & \text { Urbano \& Guerrero } \\ \text { model of an } & (2013) \\ \text { Entrepreneurial } & \text { Guerrero et al. (2014a) } \\ \text { University } & \text { Guerrero et al. (2014b) } \\ \text { (Guerrero-Cano \& } & \text { Guerrero et al. (2014c) } \\ \text { Urbano, 2012) } & \text { Guerrero et al. (2015) } \\ & \text { Guerrero et al. (2016a) } \\ & \text { Guerrero et al. (2016b) }\end{array}$

Carayannis et al. (2015),

Urbano \& Guerrero

(2013)

Guerrero et al. (2014a)

Guerrero et al. (2014b)

Guerrero et al. (2015)

Guerrero et al. (2016b)

\author{
- Interaction with civil \\ society and the media \\ - Formal factors: \\ entrepreneurial governance \\ structure, measures to \\ support entrepreneurship, \\ education for \\ entrepreneurship \\ - Informal factors: \\ university community \\ attitudes towards \\ entrepreneurship, \\ entrepreneurial teaching \\ methodologies, models and \\ reward system
}

Source: Centobelli et al. (2019)

The "Triple Helix Model" approach (Etzkowitz \& Leydesdorff, 1997) investigates the interactions between university-government-enterprise. The "Theory of entrepreneurial transformation paths" (Clark, 1998), on the other hand, has its scope in the internal structure of the university, while the "Grounded theory of university adaptation" (Sporn, 1998) provides a glimpse to the university integrated management. The "Theory of strategic actions" (Kirby, 2006) focuses on the analysis of strategic actions to promote the new mission, and the theory of "Structure of university spinoff activities" (O'shea, Allen, Chevalier, \& Roche, 2005) presents its scope in the resources used by universities.

The "University theory of entrepreneurial research" (Rothaermel et al., 2007) is the lens for the analysis of internal and external factors that influence the university, and the "Quadruple helix model" (Carayannis \& Campbell, 2009) investigates the interactions with civil society and the media. Complementarily, the "Development Model of an Entrepreneurial University" (Guerrero-Cano \& Urbano, 2012) brings as a lens the resources, capacities, structures and attitudes for the development of the Entrepreneurial University.

\section{Final Considerations}

The objective of this theoretical research was to analyze the conceptualizations and present different theoretical models that investigate the phenomenon of the Entrepreneurial University. In accordance with the definitions of the Entrepreneurial University, three predominant characteristics were evidenced: focus on the entrepreneurial activities of the members (academics and professors); focus on the contributions that the university presents to the social environment; improvement strategies in the creation of enterprises and changes in the organizational structure.

As the university's role in society expands, the image of an institution that is a source of technological innovation and economic development is projected, resulting in a trajectory of university transformation. In this transition to the Entrepreneurial University, there is a need to define a strategic direction, followed by a commitment to the knowledge developed within that university, so that it can be used mainly on a regional basis. The Entrepreneurial University is the improvement of the University of Research, which unites a linear dynamic inverse and feedback with society, which uses the problem of industry and society for research in search of solutions.

The three models explained make use of different theoretical lenses, that is, Institutional Theory and Systems Theory, which configures the relevance of studies in the area.

In view of the third mission of the Contemporary University, linked to economic and social development and to the transfer of knowledge, it infers, at the end of this theoretical article, that the systemic approach contributes significantly to the investigation of factors that establish the inter-relationship between the 
pillars of society: university, education, innovation and regional development, thereby generating the promotion of knowledges and fruitful transformations in society itself.

With an evolution from traditional teaching and research functions to activities that involve technology transfer through links with industry and dissemination of entrepreneurial thinking in the university community, as Entrepreneur Universities have facilitated organizations with the creation of an innovation infrastructure and, consequently, of evolution, with direct connections with them, or that cause economic impact on a regional and national, regional or local scale.

In this sense, the actions of the Entrepreneurial University, grounded on innovation, application of new technologies and globalization, contribute to the configuration of a space, par excellence, of generation and support to productive changes, promoting, in the social environment, favorable renovations to the development of economies.

\section{References}

Atlantic Canadian Universities Entrepreneurship Consortium (2004). Part II: An Examination of Model, Best Practices and Program Development, Nova Scodia: The Atlantic Canadian Universities Entrepreneurship Consortium.

Audretsch, D. B., Keilbach, M. C., \& Lehmann, E. E. (2006). Entrepreneurship and economic growth. Oxford University Press.

Audretsch, D. B., Hülsbeck, M., \& Lehmann, E. E. (2012). Regional competitiveness, university spillovers, and entrepreneurial activity. Small Business Economics, 39(3), 587-601.

Budyldina, N. (2018). Entrepreneurial universities and regional contribution. International Entrepreneurship and Management Journal, 14(2), 265-277.

Callon, M. P., Lare do, P. \& Mustar. (1997). The Strategic Management of Research and Technology.

Carayannis, E. G., \& Campbell, D. F. (2009). 'Mode 3'and'Quadruple Helix': toward a 21st century fractal innovation ecosystem. International journal of technology management, 46(3-4), 201-234.

Centobelli, P., Cerchione, R., \& Esposito, E. (2019). Exploration and exploitation in the development of more entrepreneurial universities: A twisting learning path model of ambidexterity. Technological Forecasting and Social Change, 141, 172-194.

Chesbrough, H. W. (2006). The era of open innovation. Managing innovation and change, 127(3), 34-41.

Chrisman, J. J., Hynes, T., \& Fraser, S. (1995). Faculty entrepreneurship and economic development: The case of the University of Calgary. Journal of business venturing, 10(4), 267-281.

Clark, B. (1998). Creating Entrepreneurial Universities: Organizational Pathways of Transformation. New York: Elsevier Science IAU Press.

Coombs, R., Harvey, M., \& Tether, B. S. (2003). Analysing distributed processes of provision and innovation. Industrial and Corporate Change, 12(6), 1125-1155.

Cunha, R. M., Maculan, A. (2015). As experiências de três Universidades fluminenses no desenvolvimento do spin-offs acadêmicos. In: Congresso latino-iberoamericano de gestão da tecnologia. Anais... Porto Alegre: Altec.,19-38.

Etzkowitz, H. (1983). Entrepreneurial scientists and entrepreneurial universities in American academic science. Minerva, 21(2), 198-233.

Etzkowitz, H. (2003). Research groups as 'quasi-firms': the invention of the entrepreneurial university. Research policy, 32(1), 109-121.

Etzkowitz, H. (2004). The Evolution of the entrepreneurial university. International Journal of Technology and Globalization, 1(1), 64-77.

Etzkowitz, H. (2013). Anatomy of the entrepreneurial university. Social Science Information, 52(3), 486-511.

Etzkowitz, H., \& Leydesdorff, L. (1997). Introduction to special issue on science policy dimensions of the Triple Helix of university-industry-government relations. 
Etzkowitz, H., Leydesdorff, L. (2000). The dynamics of innovation: from National Systems and "Mode 2" to a Triple Helix of university-industry-government relations. Research Policy, 29 (2).

Etzkowitz, H., Webster, A., Gebhardt, C., \& Terra, B. R. C. (2000). The future of the university and the university of the future: evolution of ivory tower to entrepreneurial paradigm. Research policy, 29(2), 313-330.

Etzkowitz, H., \& Zhou, C. (2017). The triple helix: University-industry-government innovation and entrepreneurship. Routledge.

Farsi, J. Y., Imanipour, N., \& Salamzadeh, A. (2012). Entrepreneurial university conceptualization: case of developing countries. Global Business and Management Research: An International Journal, 4(2), 193-204.

Fernández-Nogueira, D., Arruti, A., Markuerkiaga, L., \& Sáenz, N. (2018). The entrepreneurial university: A selection of good practices. Journal of Entrepreneurship Education, 21(3).

Grimaldi, R., Kenney, M., Siegel, D. S., \& Wright, M. (2011). 30 years after Bayh-Dole: Reassessing academic entrepreneurship. Research Policy, 40(8), 1045-1057.

Guerrero-Cano, M., Kirby, D., \& Urbano, D. (2006). A literature review on entrepreneurial universities: na institutional approach. Presented at the 3rd Conference of Pre-communications to Congresses. Business Economic Departmente, Autonomous University of Barcelona. Barceolona.

Guerrero-Cano, M., \& Urbano, D. (2012). The development of an entrepreneurial university. The Journal of Technology Transfer, 37(1), 43-74.

Guerrero-Cano, M., Urbano, D., Cunningham, J., \& Organ, D. (2014). Entrepreneurial universities in two European regions: A case study comparison. The Journal of Technology Transfer, 39(3), 415-434.

Hansen, J. A., \& Lehmann, M. (2006). Agents of change: universities as development hubs. Journal of Cleaner Production, 14(9-11), 820-829.

Jacob, M., Lundqvist, M., \& Hellsmark, H. (2003). Entrepreneurial transformations in the Swedish university system: The case of Chalmers University of Technology. Research Policy, 32(9), 1555-1569.

Jones-Evans, D., Klofsten, M., Andersson, E., \& Pandya, D. (1999). Creating a bridge between university and industry in small European countries: the role of the industrial Liaison office. R\&D Manag. 29(1), 47-56.

Kirby, D. A. (2002) 'Entrepreneurship education: can business schools meet the challenge?', International Council for Small Business - the 47th World Conference. San Juan, 16-19 June

Kirby, D. A. (2006). Creating entrepreneurial universities in the UK: Applying entrepreneurship theory to practice. The Journal of Technology Transfer, 31(5), 599-603.

Kirby, D. A., Guerrero-Cano, M., \& Urbano, D. (2011). The theoretical and empirical side of entrepreneurial universities: An institutional approach. Canadia Journal of Administrative Sciences, 28(3), 302-316.

Klofsten, M. (2008). Supporting academic enterprise: A case study of an entrepreneurship programme. New Technology-Based Firms at the New Millennium, 53-67.

Laredo, P. (2007). Revisiting the third mission of universities: toward a renewed categorization of university activities?. Higher education policy, 20(4), 441-456.

Longo, W. P. (1989). Ciência e Tecnologia: evolução, inter-relação e perspectivas. Anais do $9^{\circ}$ Encontro Nacional de Engenharia de Produção, 1, 42.

Martins, P. S. (2014). Spin-offs da ciência: terras raras do empreendedorismo acadêmico brasileiro? (Doctoral dissertation), Universidade de São Paulo, SP, Brasil.

Melo, M. B. (2014). Cultura Empreendedora na Universidade Federal de Santa Catarina: Centro Tecnológico como espaço de práticas empreendedoras. 137 f. (Dissertação de Mestrado) Universidade Federal de Santa Catarina, Florianópolis, SC, Brasil.

O'shea, R. P., Allen, T. J., Chevalier, A., \& Roche, F. (2005). Entrepreneurial orientation, technology transfer and spinoff performance of US universities. Research policy, 34(7), 994-1009.

Plonski, G. A., Carrer, C. C. (2009). A Inovação Tecnológica e a Educação para o Empreendedorismo. In: Vilela, S.; Lajolo, F.M. (Org.). USP 2034: Planejando o futuro. São Paulo: Editora da Universidade de São Paulo. 
Pugh, R., Lamine, W., Jack, S., \& Hamilton, E. (2018). The entrepreneurial university and the region: what role for entrepreneurship departments? European Planning Studies, 26(9), 1835-1855.

Redford, D. T., \& Fayolle, A. (2014). Stakeholder management and the entrepreneurial university. Handbook on the entrepreneurial university, 11-24.

Rothaermel, F. T., Agung, S. D., \& Jiang, L. (2007). University entrepreneurship: a taxonomy of the literature. Industrial and corporate change, 16(4), 691-791.

Salamzadeh, A., Salamzadeh, Y., \& Daraei, M. (2011). Toward a systematic framework for an entrepreneurial university: a study in Iranian context with an IPOO model.

Schumpeter, J. A. (1961). The theory of economic developments: an inquiry into profits, capital, credit, interest, and the business cycle. Harvard University Press.

Siegel, D. S., \& Wright, M. (2015). Academic entrepreneurship: time for a rethink? British Journal of Management, 26(4), 582-595.

Sooreh, L. K., Salamzadeh, A., Safarzadeh, H., \& Salamzadeh, Y. (2011). Defining and measuring entrepreneurial universities: a study in Iranian context using importance-performance analysis and TOPSIS technique. Global Business and Management Research: An International Journal, 3(2), 182-199.

Sporn, B. (1998). Towards more adaptive universities: Trends of institutional reform in Europe. Higher Education in Europe, 24(1), 23-33.

Sporn, B. (2001). Building adaptive universities: Emerging organisational forms based on experiences of European andu s universities. Tertiary Education and Management, 7(2), 121-134.

Trippl, M., Sinozic, T., \& Smith, H. L. (2015). The role of universities in regional development: Conceptual models and policy institutions in the UK, Sweden and Austria. European Planning Studies, 23(9), 1722-1740.

Urbano, D., \& Guerrero-Cano, M. (2013). Entrepreneurial Universities: Socioeconomic Impacts of Academic Entrepreneurship in a European Region. Economic Development Quarterly, 27(1), 40-55. 